\title{
CORE COMPETENCIES OF A CALL CENTRE AGENT
}

\author{
CHRISTINE WHITE \\ chwhite@deloitte.co.za \\ Research Psychologist \\ VERA ROOS \\ psgvr@puk.ac.za \\ Faculty of Health Sciences \\ School for Psycho-social Behaviourial Sciences: Psychology \\ North-West University
}

\begin{abstract}
Call centre agents are becoming increasingly important in the call centre context. They act as a contact point between the customer and the company. Call centre agents should have certain competencies to perform their duties sufficiently. Identifying competencies, required to be effective agents, will ease the task of training and recruitment. Due to the interrelatedness of the call centre agent, the management of a call centre and customers, all relevant role players' perceptions were taken into account. By using qualitative analysis to analyse the data, various competencies needed to function effectively in a call centre were identified.
\end{abstract}

\section{OPSOMMING}

Oproepsentrumagente word toenemend belangriker in die oproepsentrumkonteks. Hulle tree op as die kontakpunt tussen die kliënt en die maatskappy. Oproepsentrumagente behoort oor sekere bevoegdhede te beskik ten einde hulle take bevredigend te verrig. Die identifisering van bevoegdhede nodig om doeltreffend as agente te funksioneer, sal die taak van opleiding en werwing vergemaklik. Vanweë die interverwantskap tussen oproepsentrumagente, bestuur van ' $n$ oproepsentrum en kliënte, is alle betrokke rolspelers se persepsies in aanmerking geneem. Die data is kwalitatief ontleed en verskeie bevoegdhede is geiddentifiseer wat nodig is vir agente om doeltreffend in 'n oproepsentrum te funksioneer.

Keywords: effective call centre agent, competencies of call centre agents, call centre, customer satisfaction.

A call centre is an operation, consisting of as little as three people, which conducts business telephonically (Rademeyer, 1995). Dawson (1997) says "a call centre is a physical location where calls are placed, or received, in high volume for the purpose of sales, marketing, customer service, telemarketing, technical support or other specialised business activity" (p.1). Over the past few years, the call centre-concept has experienced rapid growth. Houlihan (2001) states that "the call centre processes are increasingly emerging in more specialist areas such as legal advice, psychological support, recruitment, market research and public sector communications" (p.1). Call centres are thus becoming increasingly important, both as an interaction channel as well as an important source of customer-related information. As call centres reach new levels of importance for customer relationship management, call centre agents become increasingly central within the link between companies and customers (Burgers, De Ruyter, Keen \& Streukens, 2000; Grobbelaar, Roodt \& Venter, 2004; Houlihan, 2001).

Two types of call centres exist namely an inbound and an outbound call centre. Inbound call centres refer to centres where the customer phones the call centre whereas outbound call centres require that the call centre agent phones the client (Rademeyer, 1995). Inbound call centres handle customer service in general by solving problems, handling queries or answering questions about products or services. The outbound call centre can be divided into sales and research outbound call centres. The sales outbound call centre deals with the selling of products and/or services, whereas the research outbound call centre gathers information regarding customer satisfaction, consumer behaviour or perceptions regarding products or services. This research focuses specifically on the research outbound call centre.

The perceptions of customers regarding the quality of service provided by the call centre are dependent on the performance

Requests for copies should be addressed to: V Roos, psgur@puk.ac.za of the individual agents within the call centre (Burns, 1995). When customers are delighted with the performance of the call centre agent, they will, as a result, continue their relation with the given organisation, which in turn impacts on business competitiveness (Stauss \& Mang, 1999). Call centre agents act as a contact point between the customer and the company, and can therefore be regarded as the "source of differentiation" (Burgers et al., 2000, p.2). As a result, effective call centre agents can create a competitive advantage (Stauss \& Mang, 1999).

In order for call centre agents to create this competitive advantage, they need to be competent. Kravetz (1997, p.23) states that "having the right person in the right position at the right time is critical to organisation success", as these personal competencies will result in behavioural success, which is the desired outcome. To ensure that individuals fit the required profile, it is essential to identify the key competencies and characteristics necessary for success within a particular position at a particular point in time (Kravetz, 1997). A study of women's employment in European call centres indicated that "feminine" social skills, such as communication and interpersonal skills, are considered central to an effective call centre agent (Belt, Richardson \& Webster, 2002).

Key elements of competencies include "skills, capabilities, knowledge, learning, coordination, organization and relationships" (Sanchez, 2004, p.519). Core competencies could then refer to either the assets within a person, the repeatable pattern of actions in applying the assets, as well as the skills embedded in individuals or teams that result in successful outcomes (Sanchez, 2004). Core competencies do not deteriorate over time, but are enhanced if they are applied and shared (Prahalad \& Hamel, 1990).

The aim of this article is to identify effective agents' competencies (personal attributes as well as skills), through customers' and management's perceptions. These identified competencies can be used in appointing call centre agents or when training agents that are lacking the necessary skills. 


\section{RESEARCH DESIGN}

Research approach

Qualitative research methodology is an appropriate approach to address the different, interrelated processes of a call centre (Bryman, 1988; Miles \& Huberman, 1994; Ruben, 1983; Senge, 1990; Strauss \& Corbin, 1998). Focus groups and telephonic interviewing were used to obtain data.

The data obtained using the above-mentioned methods, were verified. Verification serves the trustworthiness of the study (Guba in Creswell, 1997). The steps that were incorporated to verify the study are included in Table 1.

\section{TABLE 1}

\section{STEPS TO VERIFY THE STUDY}

\section{Verify the results through triangu- lation (Creswell, 1997; Jordan, Van Rooyen \& Strümpfe Neuman, 1997 \\ In this study two methods, namely focus groups and interviews, were used to gather data. According to Silverman (1993), triangulation can show how multiple but different qualitative measures might ve true. Results were further verified by comparing results with previous research done regarding service representatives in general.}

Competent insider At the time that the research was conducted, the performance researcher was a 'research specialist'. This, amongst (Neuman, 1997) other, entailed dealing with the call centre agents and management on a daily basis. The research specialist had to programme the telephonic questionnaire into a programme called Ronin in order for the agent to read the script to the respondent electronically. The researcher had very close contact with the call centre agents, giving briefings and getting feedback from them with regards to questionnaire design or general complaints. Due to the researcher being a part of the organisation, it was possible to interact effectively as a member and build trust with agent, management and customer groups. The researcher took a reflective position in this qualitative study.

Doing member checking (Creswell, 1997; Neuman 1997)

The results were conveyed to call centre agents and management who then judged the adequacy of the competencies identified. The participants recognised and understood the researcher's description as reflecting their call centre.

Providing a rich, \& Huberman, 1994) settings because of shared characteristics.

Keeping a register of data (Miles \& Huberman, 1994)

Notes of relevant events and the state of affairs were made and regularly studied while analysing the data

Providing a detailed A detailed description of how the project was description of the process (Miles \& Huberman, 1994; Neuman, 1997). conducted was provided. This involved a precise description of the selected subjects, the concepts used, theoretical ideas and research methods. Neuman (1997) refers to this as the natural history of the project. Outsiders reading the study can see and follow the researchers' actions exactly.

Auditing for future The research report was sufficiently detailed for a researchers (Jordan, secondary researcher to arrive at similar conclusions Van Rooyen \&

Strumper, 2002; Miles

\& Huberman, 1994)

The mechanisation of registration

(Neuman, 1997)

Another measure to verify the data was to use tap recordings, which were transcribed, in order to ensure correct reporting of results.

\section{Context of research}

The call centre used in this specific study was established in 1994 as a one-woman operation at home and has now grown to include a staff of 72 people. There are 30 permanent call centre agents and five temporary agents. Computer Aided Telephone Interviews (CATI) is the nerve of the company and process up to 5000 interviews per day. The function of the centre is to conduct research by means of telephonic interviews. The aim of the interviews is to determine amongst other things customers' satisfaction and consumer behaviour, to gather valuable product information and to perform internal culture and climate studies. The agents call the customers, ask questions and record their answers. As the call centre under discussion does not contact their own customers, but rather their clients' customers whom they call participants, the call centre agents play a very important role in customer satisfaction as customers associate the research call centre agent with the organisation the research is being done for. The research organisation's customers' customers thus also become the research organisation's customers.

\section{Participants}

Different types of sampling were used to select participants for the different groups. For the management focus group, all six managers were invited to participate in the management focus group. To select eight call centre agents out of the 30 call centre agents in this specific call centre, simple random sampling was used (Babbie, 1989; Neuman, 1997; McBurney, 1994). The ten customers were selected by using simple random sampling. Ten customers were interviewed telephonically for the purpose of this study. The ages of the customers varied between 20 and 45 . Five of the participants were female and five were male. All the customers have completed high school or a higher qualification. Each customer in the database of the call centre who had been contacted within the previous month was numbered. These customers were selected because the interview was still fresh in their memories and they could give valuable responses to the questions. Again after numbering all the elements in the sampling frame, a random number table was used to decide which elements to select (Babbie, 1989; Neuman, 1997; McBurney, 1994).

To ensure that the participants' rights were protected during the research process the guidelines proposed by Neuman (1997) were followed. Each participant was given a brie description of the purpose and procedure of the research. The customers were informed of the expected duration of the telephonic interview. All participants were guaranteed anonymity and all the records were treated as confidential Neuman's (1997) suggestion that a summary of the findings should be presented was followed and a presentation about the findings were made to the call centre management and agents to verify the results (refer to table 1 ). The call centre agents and management then judged the adequacy of the identified competencies.

\section{Procedure}

Focus groups, which allow for the explicit use of group interaction to produce data and insights that would be less accessible without the interaction found in a group (Morgan, 1990; Ward, Bertrand \& Brown, 1991), were used to access data from call centre agents as well as the management of a call centre. Computer-assisted telephonic interviewing (CATI), which involves the making of a call to a participant, asking the participant open-ended questions and recording the answers (Neuman, 1997), was used to obtain information from the customers that have been served previously by a call centre agent. The questions that the interviewer ask are carefully worded and arranged in order to have the same sequence and same wording for each participant (Patton, 1990).

Two focus groups were conducted. One group was conducted with call centre agents and the other with management. These groups were not combined for fear of restricting responses; where call centre agents might hold back in front of management or where management might not want to revea certain issues in front of their staff. The first focus group consisted of eight call centre agents between the ages of 22 and 
32. Four of the participants are male and four female. All eight have completed school or have a higher education. The focus group of the participants from management consisted of six participants between the ages of 20 and 45. Five of the six participants were female. All six have completed school, and five have a diploma.

The main question to start the focus group was: "What do you think are important competencies to be an ideal call centre agent?"

Ten customers were recruited from the call centre's database to partake in this interview. The interview lasted approximately 15 minutes.

\section{Analysis of the data}

The telephonic interviews and focus groups were taperecorded with the participants' permission and afterwards transcribed verbatim. The transcribed interviews and focus groups were read and reread until a sense of totality was obtained. The idea was to conceptualise the data in order to make sense of it (Neuman, 1997). The data analysis comprised search for patterns in data. The categorising of the data allowed the researcher to make comparisons more effectively and lays the basis for making new connections between different bits of data (Dey, 1993). Creswell (1997) states that analysing qualitative data is a process of moving in analytic circles rather than a fixed linear approach. Data were analysed until data saturation was achieved. Consequently in this study discussions were held until no more information was needed (Creswell, 1997; Jordan, Van Rooyen \& Strumpher, 2002; Neuman, 1997). Common features promoted by several authors (Berg, 1998; Creswell, 1997; Miles \& Huberman, 1994; Neuman, 1997; Strauss \& Corbin, 1998) were used as guide for the content analysis of the data. The data were analysed in the following three steps.

In this first step, themes were located and initial codes were assigned to organise the data into categories (Creswell, 1997; Neuman, 1997). The second step involved the initial broad themes or statements compiled in step one. All these broad themes (sub-themes) were grouped together as main themes. Strauss and Corbin (1998) state that the purpose of axial coding is to group the data that were fractured during open coding. The focus of this step was on the categories assigned in step one and not on the data; and the aim was to review and examine these initial categories (Neuman, 1997). In this step the researcher explored causal conditions, asked about causes and consequences, conditions and interactions, strategies and processes (Creswell, 1997; Neuman, 1997). Also, during axial coding, the researcher interconnected the categories by looking for categories or concepts that cluster together. In the final step, the different categories identified in axial coding were integrated and refined (Creswell, 1997; Strauss \& Corbin, 1998). The previous categories were examined to make comparisons and contrasts after data collection was complete. Neuman (1997) refers to this as selective coding. The different groups from which the data have been obtained (agents, customers and management) were used as multiple indicators to inform the research objective.

\section{RESULTS}

The three steps that have been described are illustrated below. It only serves as an example of the process of analysis.

The process open and axial coding is illustrated in tables 2 and 3 . This is only one identified attribute, namely communication. All identified attributes were analysed in a similar manner. The general aim of this step is to interconnect the broad categories identified in the open coding.
TABLE 2

ILLUSTRATION OF DATA ANALYSIS

\begin{tabular}{|c|c|}
\hline Response & Open coding \\
\hline \multicolumn{2}{|l|}{ Moderator introduction } \\
\hline \multicolumn{2}{|l|}{$\begin{array}{l}\text { To start off with I want to know what you } \\
\text { like about being a call centre agent. What } \\
\text { about being a call centre agent makes } \\
\text { you tick? }\end{array}$} \\
\hline $\begin{array}{l}\text { Participant A: I would say it is talking to } \\
\text { different people about the same thing and } \\
\text { getting different opinions. Talking to these } \\
\text { different people develops you as a person. } \\
\text { Because people may say to you whatever } \\
\text { they want, but you are not allowed to say } \\
\text { how you feel, because you must stick to } \\
\text { your script. There is a way they talk to you } \\
\text { and a way you must talk to them. }\end{array}$ & $\begin{array}{l}\text { - Talking } \\
\text { - To different people } \\
\text { - Getting different } \\
\text { opinions } \\
\text { - Not allowed to say how } \\
\text { you feel } \\
\text { - Certain way you talk } \\
\text { to them }\end{array}$ \\
\hline $\begin{array}{l}\text { And that is what you like about your job? } \\
\text { Talking to these different people and } \\
\text { getting different responses to the same } \\
\text { question? }\end{array}$ & \\
\hline $\begin{array}{l}\text { Participant A: Yes, talking to different people } \\
\text { and improving in this way your } \\
\text { communication skills. }\end{array}$ & $\begin{array}{l}\text { - Talking to different } \\
\text { people } \\
\text { - Improving } \\
\text { communication skills }\end{array}$ \\
\hline $\begin{array}{l}\text { Participant A: What I also like is that you } \\
\text { shouldn't bow down, tell what you want - } \\
\text { but at the same time with respect and being } \\
\text { tactful. And the day when you get home as an } \\
\text { agent, you must feel; Wow! Can you believe } \\
\text { I did this and who says I can't speak to } \\
\text { anyone? At the end of the day you speak to } \\
\text { so many different people, from a student at } \\
\text { the university to a managing director of a } \\
\text { big company. This makes me feel some sort } \\
\text { of satisfaction. }\end{array}$ & $\begin{array}{l}\text { - Do not bow down } \\
\text { - Respect } \\
\text { - Tact } \\
\text { - Speaking to different } \\
\text { people } \\
\text { - Speaking to people of } \\
\text { different status }\end{array}$ \\
\hline
\end{tabular}

TABLE 3

ILLUSTRATION OF INTERCONNECTION OF BROAD CATEGORY

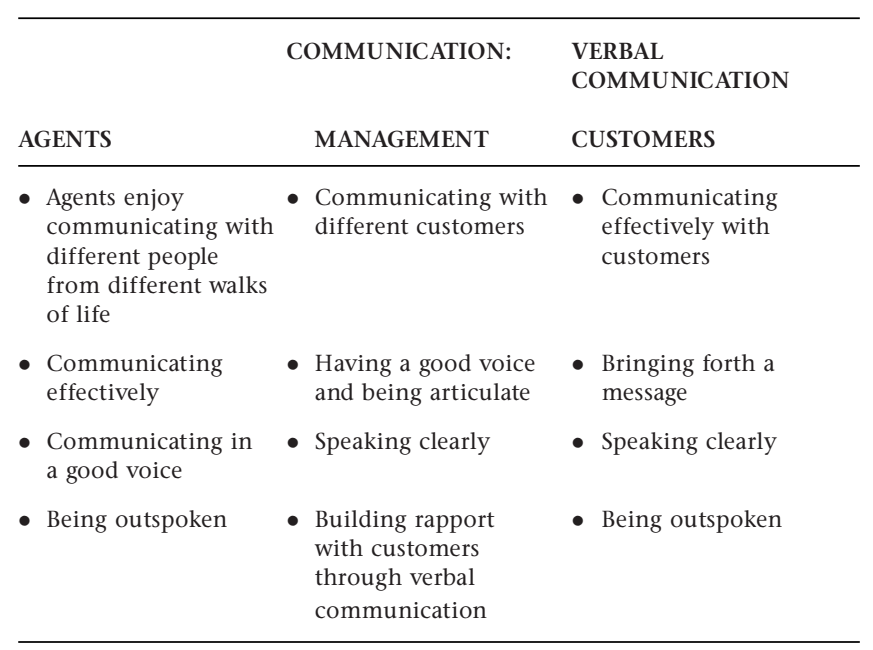

\section{DISCUSSION}

A discussion of the skills and attributes that have been identified in the research follows next.

\section{Communication}

It is clear that all three groups think an effective call centre agent should have the skills to communicate effectively, both verbally and non-verbally. The importance of communication for a call centre agent is emphasised in literature and from the results 
presented in this study. Vetere and Gale (1987) state that within a system all processes depend upon a flow of information from and to the call centre agent in the form of instructions or constraints. Ruben (1983) adds that communication is the most basic life process and is the process of transforming information in order to adapt to the environment. It seems as if effective communication is also regarded as an important competency in other service environments as indicated by Grobbelaar et al. (2004) in a financial institution.

The literature reported that an ideal call centre agent should have the skills to effectively convey ideas and information (Barnhart, 2000) and should be able to understand customers and be able to apply effective questioning techniques (Freeman \& Rusnell, 2000).

The results explained the competency communication further by noting that communication skills include the ability to communicate with different people in a professional way without personal feelings influencing the process. Effective verbal communication includes the ability to communicate with people from different walks of life, the ability to build rapport with the customer, the ability to provoke an interest in the research from the customer and in so doing, induce and maintain a reaction from the customer. Communicating effectively also includes more general aspects such as being outspoken, having a good voice and speaking clearly.

Although the literature (Barnhart, 2000; Boshoff, 1999) states that service representatives should also be able to communicate effectively through written communication, no reference was made of this in the particular study. The conclusion is thus that in this particular call centre under study, written communication is not a competency required to be an effective call centre agent as they only capture responses by typing exactly what the participant is saying and do not have to do any formal writing.

Communication also includes non-verbal communication, which includes hesitations, shifts in tempo of speech, overtones of voice and so on, that the customer can hear over the phone. Customers want the communication to take place in a conversational tone. Bateson (1972) believes that non-verbal communication is more important than verbal communication as this provides the customer with the underlying message that agents do not want to convey through verbal communication, such as that they are upset (faster tempo); tired (a yawn) or unsure (hesitation).

\section{Listening}

The ability and desire to listen actively, is an important competency for an effective call centre agent (Barnhart, 2000; Grobbelaar et al., 2004). Listening skills also include the ability to respond to the statements and comments of others; to use reflective responses and clarifying questions to assure the other person that they have been heard and the ability to remember notable points covered by the customer (Barnhart, 2000; Charos, 1999; Competencies on target, 2001). When agents do not listen to the feedback from the customer, mistakes may become greater as agents do not take action based on the feedback (Ruben, 1983).

The following competencies were not identified in the literature, but became evident from the results of this research: the ability to listen without being distracted by surroundings or personal matters, sounding interested in everything customers have to say and the ability to correctly capture everything the customer says.

\section{Attentiveness}

A critical competency of an effective call centre agent was found to being attentive. Being attentive and detail-focused is an important concept in systems thinking as it allows the call centre agent to focus on the customer as a whole and also to keep detail such as the context of the customer in mind (Senge, 1990).

The literature explains being attentive as having a concern for accuracy and quality (Competencies on target, 2001), correctly completing work, monitoring and checking work (Freeman \& Rusnell, 2000); and finally delivering on promises dependently and accurately (Bennington, Cummane \& Conn, 2000; Spencer \& Spencer, 1993).

The results of this research assert that attentiveness is the ability to correctly capture relevant responses; the ability to gather accurate and detailed information; the ability to raise accurate points and the ability to be thorough and detail-focused.

\section{Understanding}

Whilst the literature uses the word empathy (Parasuraman, Zeithaml \& Berry, 1988), the results found this competency better described as understanding. From the literature and the results, being understanding includes understanding the customers' predicament and making an effort to understand the customers' specific needs. Providing the customer with caring, individualised attention also forms part of being understanding. The literature states that understanding includes what the customers are feeling and what their motives and concerns are (Boshoff \& Allen, 2000; Spencer \& Spencer, 1993).

An ability to understand includes having a balance between being neutral and getting involved; and being considerate to the customers' situation by, for example, phoning back at a later, more convenient time. Although agents are pressed for a certain number of interviews, they should at all times be understanding and give customers the opportunity to finish their complaint regardless of its relevance. Understanding agents should remain professional at all times and not let personal opinions and beliefs influence their understanding of the customers' situation

\section{Attitude}

A call centre agent's attitude will influence the customers' attitude. For example, if the call centre agent has a friendly attitude, it will pull for an even friendlier response from the customer. For this reason it is important that a call centre agent has the correct attitude. The literature and results state that a call centre agent (or service representative) should be friendly, considerate, selfmotivated, professional, helpful and pleasant (Boshoff, 1999; Career Services, 2001; Lorimer, 1999).

Call centre agents should remain positive and energetic throughout the day; have a good sense of humour and go out of their way to help the customer and answer any questions or solve any problems the customer has. Ideal call centre agents will be polite and patient by being willing to repeat questions, explain confusing questions in the questionnaire, answer the customers' questions and give customers the opportunity to state their case. Customers should always be treated with respect, even when they are abusive. In such cases, the interview should be ended with tact. The approach towards a customer is very important. If the approach is wrong or the introduction does not create an interest, then the interview is likely to fail.

\section{Consistency}

No evidence of this competency was found in the literature. A call centre agent should be consistent throughout the day. Being consistent includes having a positive attitude throughout the day and not letting personal matters influence interaction with the customer. Furthermore consistency includes maintaining a balance between being impartial and getting emotionally involved. It means that the agent treats all customers in the same way. 


\section{Confidence}

Again no evidence was found in the literature regarding this competency. Having confidence will ensure that the customers accommodate agents by participating in the interview. Confidence also assists agents to deal with rude customers. A confident agent is brief and to the point.

The results confirm the literature by saying having confidence will put the agent in charge of the interview. The call centre agent has the power to decide whether to continue with the interview or not. When customers become abusive, agents can end the interview. Agents should not let the customer talk about irrelevant matters, but should remain in control of the interview in a professional manner.

\section{Knowledge}

An effective call centre agent should be knowledgeable. Senge (1990, p.283) feels that this knowledge should not be "compartmentalised", as compartments creates a false sense of confidence. The literature specifically emphasises product or service knowledge (Grobbelaar et al., 2004). This involves the benefits, usage and features of the product or service (Career Services, 2001; Freeman \& Rusnell, 2000). Agents should be able to acquire and then apply knowledge quickly.

The results verify product knowledge as being essential, but add that a call centre agent should also be knowledgeable regarding the research, the company, research methods and the terminology of the research project. The results show that the agent should have adequate knowledge in order to answer all the customers' questions, whether these concern products, services, the company itself or the research.

\section{Speed}

The literature notes that, although customers require accuracy and detail, they still want their requests to be solved in a timely manner (Boshoff, 1999; Jones \& Jaebeom, 1997). From the results it is evident that acquiring all the identified competencies, for example confidence, knowledge and basic telephone manner, will contribute to a speedy interview. Agents suggest that better typing skills would lead to a faster interview.

\section{Unpredictability as a challenge}

In the literature no mention is made of the unpredictability of the call centre. The results, however, repeatedly indicate that the call centre is an unpredictable setting accompanied by various challenges. Agents feel that studying questionnaires, having briefing sessions and dealing with similar difficult situations will assist in making the call centre a more predictable setting. According to Levine and Fitzgerald (1992), as the call centre as a system develops, its dynamic structure emerges as a results of feedback processes. Call centre agents should find adapting to the demands of the feedback a challenge.

\section{Flexibility}

In the literature, flexibility is defined as the ability and willingness to change, keep an open mind, implement new approaches, maintain objectivity, be resilient and manage the process of change (Grobbelaar et al., 2004). Flexibility also includes the ability to conform to procedures and adapt to certain processes (Spencer \& Spencer, 1993). The results confirm this and contribute by saying agents should be flexible in order to deal with customers from various walks of life and adapt to their specific needs. Agents should not compromise professionalism in any situation, but still be flexible and adapt to the requirements of the situation. Flexibility and adaptability should therefore be qualities to consider when recruiting new agents.

\section{Language}

The existence, functioning and development of the call centre agent, requires continual exchanges with different contexts. This exchange can take place in the form of communication. Ford and Lerner (1992) believe that meanings can be communicated if different individuals have the same linguistic images linked to similar abstract representations. Understanding each other's language will activate one another's abstract and imagistic representations.

Although the literature makes no reference to language in particular, the importance of language in a call centre setting is evident. Customers prefer to conduct the interview in their language of choice.

\section{Stress tolerance}

Stress causes a variable to take on a value close to the higher or lower level of the next variable, resulting in a lack of flexibility. To ensure flexibility in the call centre, it is important to keep stress levels as low as possible. The call centre environment is a stressful environment in which agents must deal with rude, demanding, or distraught customers, face crises, work with new and complicated technology and constantly monitor each call (Peter, 2001). Contributors to stress also include pressure from management, who expect a certain number of calls in a certain time frame. Working in a team and contributing to the team effort can also cause stress if your performance is lower than the other agents' performance. Being stress tolerant is the ability to perform under conditions where pressure, resistance or opposition makes completing the work difficult (Competencies on target, 2001). Being stress tolerant is the ability to remain productive in times of crisis or critical events (Barnhart, 2000).

\section{Goal-orientation}

Although the literature does not refer to the importance of being goal-driven, the importance of this competency becomes apparent in the results. Call centre agents should be goal-driven in order to reach targets set by management.

\section{Proactive problem solving}

Senge (1990) states that being proactive means being in charge of your future. Proactiveness comes from "seeing how we contribute to our own problems" (Senge, 1990, p.21). In the literature, problem-solving skills are explained as representing an analytical thinking process in order to solve problems. This is reflected in call centre agents' ability to gather information and select the best possible solution. Problem-solving skills include practical intelligence, reasoning, planning skills and creative thinking (Barnhart, 2000; Competencies on target, 2001; Freeman \& Rusnell, 2000; Spencer \& Spencer, 1993).

The results contribute by saying that customers sometimes require information a call centre agent is not supplied with. The call centre agent must have initiative, be a quick thinker, and provide the customer with this information.

\section{Teamwork}

The literature highlights the importance of collaboration, work relationships and the ability to work in a team. Teamwork implies working cooperatively with others, which requires interpersonal skills (Spencer \& Spencer, 1993). The necessity of an ideal call centre agent being able to work independently and also in a team became evident in this study. Poor work performance will influence the entire teams' performance. Management should train agents to work in a team or should aim to recruit team players who are also able to work individually.

\section{Basic telephone and technology skills}

The literature states that all call centre agents must have the ability to apply computer or telephone technology. Other basic skills include typing skills and retrieving information from the database (Career Services, 2001; Competencies on 
target, 2001; Freeman \& Rusnell, 2000). The results confirm this by noting that basic knowledge that agents should possess before starting to work in the call centre includes typing skills, a good telephone manner and computer literacy. An effective agent will possess basic telephone skills such as how to greet customers appropriately, how to use the participants' name throughout the interview and how to read properly.

\section{CONCLUSIONS}

From the results it emerged that an effective agent should have the competencies, including personal attributes and skills to communicate effectively with different people in a professional way, without personal feelings influencing the process. The agent should listen without being distracted by surroundings or personal matters. An effective agent would be attentive, ensuring accurate and detailed information. The agent would show understanding of the customers' predicament and make an effort to understand the customers' specific needs. Having the 'correct' attitude includes being friendly, considerate, self-motivated, professional, helpful, confident and pleasant. An effective agent would consistently maintain a friendly and professional attitude, regardless of the customer's attitude, the time of day, or any personal matters. They would stay in control of the interview at all times; be a knowledgeable agent who has knowledge regarding the product or service, the research, the company, research methods and the terminology of the research project.

An effective agent would be able to deliver quality working in a short period of time and deal with the unpredictability of the call centre as a challenge. This unpredictability also calls for flexibility and adaptability to the demands of the situation. One manner in which flexibility could be fostered is by being multilingual. In any stressful situation an agent would be able to deal with stress and remain productive in times of crisis or critical events.

Effective call centre agents would be goal-driven, have initiative, be quick thinkers, solve problems quickly and be able to work independently and also in a team. The effective call centre agent should have basic telephone and technological skills such as speedy typing, a good telephone manner and computer literacy.

In similar research (Grobbelaar et al., 2004) many of the competencies that were identified in this research, were also identified. The results of both research, which has been conducted in different environments, can not be generalised to other contexts, since it focus on competencies in helping others, "rather than on business outcomes or technical processes" (Grobbelaar et al. 2004, p.17). However, it is very interesting to see the emerging field of competencies that are generic in terms of service environments, but also unique in relation to the specific context.

\section{SUGGESTIONS FOR FURTHER RESEARCH}

This research only focused on an outbound call centre; the same research can be conducted with an inbound call centre. The results would determine if agents working in an outbound call centre require different competencies than those working in an inbound call centre and vice versa. Emerging from the results is the fact that cultural concerns in a call centre are mostly related to crosscultural issues rather than interracial issues (Ruben, 1983). Clearly there is a need to explore communication between different cultures and how cross-cultural issues affect interaction over the phone.

\section{REFERENCES}

Babbie, E.(1989). The practise of social research (5th ed.). Cape Town: Wadsworth.

Barnhart, R. (2000). What is a competency? COMPET Consulting. Retrieved October, 2002, from http://www.competinc.com.

Bateson, G. (1972). Steps to an ecology of mind. New York: Ballantine Books.

Belt, V., Richardson, R. \& Webster, J. (2002). Women, social skill and interactive service work in telephone call centres. New Technology, Work and Employment, 17 (1), 20-34.

Berg, B.L. (1998). Qualitative research methods for the social sciences. London: Allyn and Bacon.

Bennington, L., Cummane, J. \& Conn, P. (2000). Customer satisfaction and call centres: An Australian study. International Journal of Service Industry Management, 11 (2), 162-173

Boshoff, C. (1999). RECOVSAT: An instrument to measure satisfaction with transaction-specific service recovery. Journal of Service Research, 1 (3), 236-249.

Boshoff, C. \& Allen, J. (2000). The influence of selected antecedents on frontline staff's perceptions of service recovery performance. International Journal of Service Industry Management, 11 (1), 63-90.

Bryman, A. (1988). Quantity and quality in social research. London: Unwin Hyman.

Burgers, A., De Ruyter, K., Keen, C. \& Streukens, S. (2000). Customer expectation dimensions of voice-to-voice service encounters: A scale development study. International Journal of Service Industry Management, 11 (2),112-113.

Burns, J. (1995). Developing and implementing a customer contact strategy. MCB Managing Service Quality, 5 (4), 960-974.

Career Services. (2001). Retrieved August, 2002, from www.lsc.gov.uk/news_docs/YouthSurvey.PDF.

Charos, M. (1999). Improve telephone agents' listening skills. Telebusiness Partners - CallCraft. Retrieved October, 2002, from http://www.iew3.technion.ac.il/serveng/References/ccbib.ps.

Competencies on target. (2001). Online call centre recruitment and assessment solutions. Retrieved October, 2002, from http://www.impart.com.au/documents/Competencies_on_T arget.doc.

Creswell, J.W. (1997). Qualitative inquiry and research design: Choosing among five traditions. London: Sage.

Dawson, K. (1997). The role of the call centre. Retrieved October, 2001, from http://www.realmarket.com.

Dey, I. (1993). Qualitative data analysis: A user-friendly guide for social scientists. New York: Routledge.

Ford, D.H. \& Lerner, R.M. (1992). Developmental systems theory: An integrative approach. Newbury Park: Sage.

Freeman, B. \& Rusnell, D. (2000). Selection advantage assessment results and observations. Kingston call centre expo. Retrieved October, 2002, from http://business. kingstoncanada.com/Expo-KaplanReport.pdf.

Grobbelaar, R.L., Roodt, G. \& Venter, A. (2004). Critical competencies to promote a customer service core capability in a human resources call centre. South African Journal of Human Resource Management, 2 (3), 16-24.

Houlihan, M. (2001). Managing to manage? Stories from the call centre floor. Journal of European Industrial Training, 25 (2), 112-113.

Jones, M.A. \& Jaebeom, F. S. (1997). Transaction-specific satisfaction and overall satisfaction:an empirical analysis. Journal of Services Marketing. 14 (2),147-159.

Jordan, P.J., Van Rooyen, D. \& Strumpher, J. (2002). The lived experience of patients on mechanical ventilation. Health $S A$ Gesondheid, 7 (4), 24-37.

Kravetz, D.J. (1997). What is a job competency? Building a job competency database. Retrieved October, 2001, from http://www.kravetz.com/art2/art2p2.html.

Levine, R.L. \& Fitzgerald, H.E. (Eds).(1992). Analysis of dynamic psychological systems. Basic Approaches to general systems, dynamic systems and cybernetics. New York: Plenum Press. 
Lorimer, I. (1999). Targeting Skills. Callcraft. Retrieved January, 2003, from http://209.130.20.20/now/MANAGE/people/ targeting.htm.

McBurney, D.H. (1994). Research methods (3 ${ }^{\text {rd }}$ ed.). Pacific Grove: Brooks/ Cole.

Miles, M.B. \& Huberman, A.M. (1994). Qualitative data analyses. Thousand Oaks: Sage.

Morgan, D.L. (1990). Focus groups as qualitative research. Newbury Park: Sage.

Neuman, W.L. (1997). Social research methods: Qualitative and Quantitative approaches. Boston: Allyn and Bacon.

Parasuraman, A., Zeithaml, V.A. \& Berry, L.L. (1988). Servqual: A multiple-item scale for measuring consumer perceptions of service quality. Journal of Retailing, 64, 12-40.

Patton, M.Q. (1990). Qualitative evaluation and research methods. Newbury Park: Sage.

Peter, D. (2001). Band Aid does not fix stress in call centres. Retrieved July 2001, from http://wwwsatelelink.com/ people.htm.

Prahalad, C. K. \& Hamel, G. (1990). The core competence of the corporation. Harvard Business Review, 68 (3), 79-91.
Rademeyer, D. (1995). A benefits model for the call centre strategy. Unpublished dissertation, Rand Afrikaans University, Johannesburg. Ruben, B.D. (1983). A system-theoretic view. Intercultural community theory: current perspectives. London: Sage.

Sanchez, R. (2004). Understanding competence-based management. Identifying and managing five modes of competence. Journal of Business Research, 57, 518-532.

Senge, P.M. (1990). The fifth discipline: The art and practice of the learning organization. New York: Doubleday/Currency.

Stauss, B. \& Mang, P. (1999). Cultural shocks in inter-cultural service encounters. Journal of Services Marketing, 13 (4), 329-346.

Strauss, A.L. \& Corbin, J.M. (1998). Basics of qualitative research: Techniques and procedures for developing grounded theory. London: Sage.

Spencer, L.M. \& Spencer, S.M. (1993). Competence at work: Models for superior performance. New York: John Wiley and Sons.

Vetere, A. \& Gale, A. (1987). Ecological studies of family life. Chichester: John Wiley and Sons.

Ward, V.M., Bertrand, J.T. \& Brown, L.F. (1991). The comparability of focus group and survey results: Three case studies. Evaluation Review, 15 (2), 266-283. 